\title{
Surprising cause of a hoarse voice
}

\author{
Laura Leach, Sheneen Meghji, Eishaan Bhargava, Furrat Amen
}

Department of

Otorhinolaryngology, North West Anglia NHS Foundation Trust, Peterborough, UK

\section{Correspondence to Laura Leach,}

laura.leach1@nhs.net

Accepted 28 March 2018

\section{DESCRIPTION}

A 78-year-old woman presented to our otorhinolaryngology clinic with a 5 -year history of gradually progressive, worsening dysphonia, associated with some recent weight loss. She denied any dysphagia, odynophagia, otalgia, dyspnoea or neck lumps. She had a significant cardiovascular history and was a non-smoker with no alcohol intake. Using the grade-roughness-breathiness-asthenicitystrain scale, the patient scored a $2 / 3$ for grade and breathiness, $1 / 3$ for roughness and $3 / 3$ for strain. On examination, there was a large left-sided posterior pharyngeal wall swelling occluding most of the oropharynx (figure 1). It was firm, non-pulsatile and non-tender, with a normal overlying mucosal appearance. Flexible nasoendoscopy demonstrated that this swelling extended from the level of the soft palate to just below the level of the epiglottis, with laryngeal displacement to the right. However, there

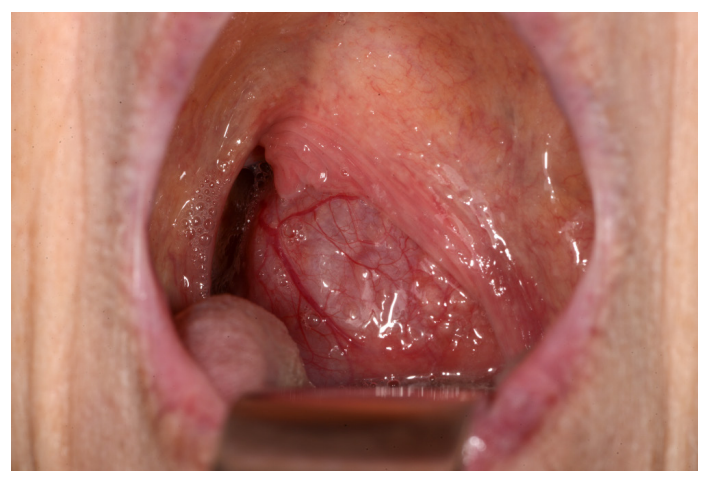

Figure 1 Clinical photograph of the oral cavity demonstrating a large left-sided posterior pharyngeal wall swelling, occluding most of the oropharynx. was no airway compression, and the patient had normal, mobile true vocal cords bilaterally. Videolaryngostroboscopy was not possible with our rigid scope due to the size of the mass in the oropharynx. Examination of the neck was unremarkable, and cranial nerve examination revealed intact cranial nerves IX, X, XI and XII.

An MRI base of skull to suprasternal notch was arranged urgently, which showed a well-defined lobulated vascular mass measuring $6 \mathrm{~cm}$ in maximal diameter, splaying the origins of the left internal and external carotid arteries. The mass filled the parapharyngeal space extending across the midline of the oropharynx, with displacement of the left piriform fossa (figure 2). The appearance was consistent with a large carotid body tumour (CBT).

Following multidisciplinary team (MDT) discussion, the tumour was deemed too large to be surgically resectable in a patient with complex cardiac comorbidities and who was asymptomatic apart from the dysphonia. In light of the risks of fineneedle aspiration in a highly vascular tumour, especially in a case with good clinical suspicion of CBT on MRI, no cytology was performed. The decision was to treat conservatively with support from our otorhinolaryngology specialist nurse, and the patient has not developed any further symptoms in the last 3 months since follow-up.

A CBT is a paraganglioma arising at the carotid bifurcation and is derived from neuroectodermal tissue. These are highly vascular, generally slowgrowing benign tumours that can remain asymptomatic and therefore undetected for years. Classically, patients with CBTs present with a non-tender, rubbery neck lump, with or without associated cranial nerve palsies due to local invasion or
Check for updates

To cite: Leach L, Meghji S, Bhargava E, et al. BMJ Case Rep Published Online First: [please include Day Month Year]. doi:10.1136/bcr-2018224686
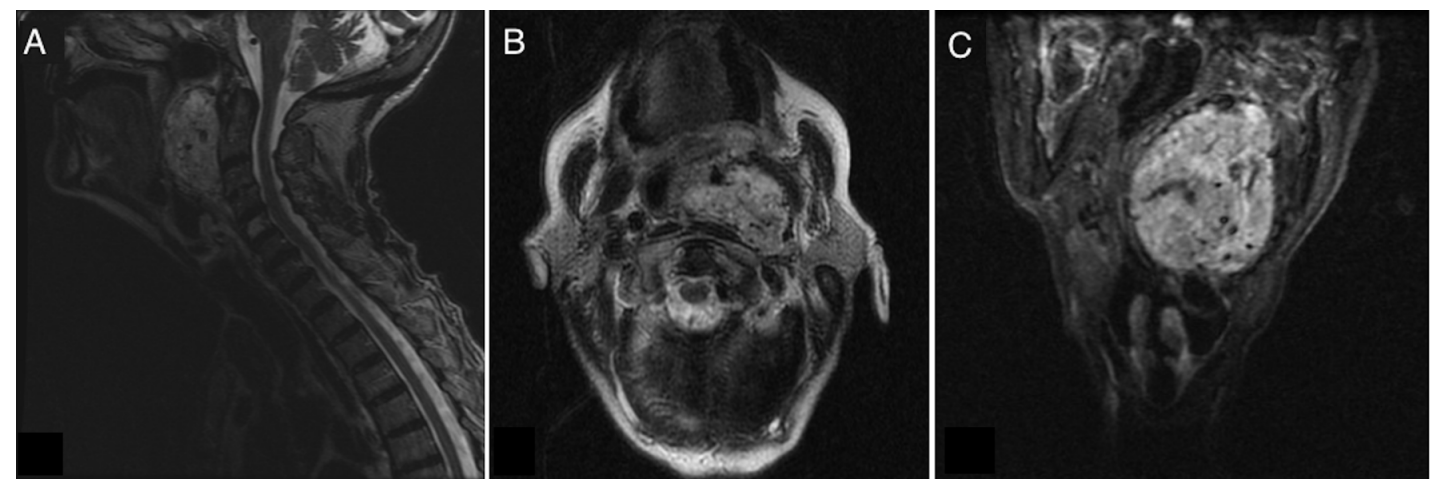

Figure 2 Sagittal (A) and axial (B) T2-weighted MR images demonstrating a lobulated vascular mass filling the parapharyngeal space, with splaying of the left external and internal carotid arteries around the mass (B). Coronal short tau inversion recovery (STIR) sequence MR image (C) demonstrating the mass extending across the midline of the oropharynx, with displacement of the left piriform fossa. The image also demonstrates the classical 'salt and pepper' appearance seen in CBTs, due to punctate flow voids and regions of haemorrhage or slow flow. CBTs, carotid body tumours. 
compressive symptoms with dysphonia, dysphagia and syncope. ${ }^{1}$ To our knowledge, this is the first case described in the literature of a patient with a CBT presenting with dysphonia alone. The breathiness of the patient's voice supports the possibility of vagal impairment. This would have been more evident with videolaryngostroboscopy, which is the gold standard for assessing voice dysfunction, and is an argument for clinics to have access to a flexible videostroboscope to allow for assessment in cases such as this one where the use of a rigid scope is not possible.

Complete surgical excision is usually the treatment of choice; however, this can be technically challenging due to the highly vascular nature of CBTs and their close association with cranial nerves and the carotid bifurcation. Advanced CBTs can be intimately adherent to the carotid vessels (classified by Shamblin et al as type III). ${ }^{2}$ Early diagnosis and excision is therefore crucial

\section{Learning points}

- Carotid body tumours (CBTs) may present with dysphonia as the only symptom or sign.

- A history of non-resolving dysphonia, even if mild, always necessitates prompt investigation.

- Early diagnosis and surgical excision is important for successful management of CBTs in order to prevent mortality and reduce morbidity such as neurological damage and vascular sacrifice. for successful management; larger tumours are associated with a higher rate of intraoperative complications including nerve injury and bleeding, a higher chance of requiring vascular sacrifice and have poorer overall postoperative outcomes. ${ }^{3}$ Preoperative embolisation can facilitate surgical excision; however, it is reserved for larger tumours due to the increased risk of stroke. ${ }^{3}$ Sadly, many patients, like in this case, present too late for surgical excision to be viable.

Contributors LL: drafting of manuscript. SM, EB and FA: reviewing and revising of manuscript.

Funding The authors have not declared a specific grant for this research from any funding agency in the public, commercial or not-for-profit sectors.

Competing interests None declared.

Patient consent Obtained.

Provenance and peer review Not commissioned; externally peer reviewed.

(c) BMJ Publishing Group Ltd (unless otherwise stated in the text of the article) 2018. All rights reserved. No commercial use is permitted unless otherwise expressly granted.

\section{REFERENCES}

1 Prabakaran S, Subburayulu AS, Ravikumar PT. Surgical Excision of Carotid Body Tumor Through Modified Approach-A Case Report. J Maxillofac Oral Surg 2016;15:251-5.

2 Shamblin WR, ReMine WH, Sheps SG, et al. Carotid body tumor (chemodectoma). Clinicopathologic analysis of ninety cases. Am J Surg 1971;122:732-9.

3 Dixon JL, Atkins MD, Bohannon WT, et al. Surgical management of carotid body tumors: a 15-year single institution experience employing an interdisciplinary approach. Proc 2016;29:16-20.

Copyright 2018 BMJ Publishing Group. All rights reserved. For permission to reuse any of this content visit

http://group.bmj.com/group/rights-licensing/permissions.

BMJ Case Report Fellows may re-use this article for personal use and teaching without any further permission.

Become a Fellow of BMJ Case Reports today and you can:

- Submit as many cases as you like

- Enjoy fast sympathetic peer review and rapid publication of accepted articles

- Access all the published articles

Re-use any of the published material for personal use and teaching without further permission

For information on Institutional Fellowships contact consortiasales@bmjgroup.com

Visit casereports.bmj.com for more articles like this and to become a Fellow 